\title{
CTRC Gene Mutation
}

National Cancer Institute

\section{Source}

National Cancer Institute. CTRC Gene Mutation. NCI Thesaurus. Code C128818.

A change in the nucleotide sequence of the CT RC gene. 